Sabrina P. Ramet, Marko Valenta (eds)

\section{Ethnic Minorities and Politics in Post-Socialist Southeastern Europe}

Cambridge: Cambridge University Press, 2016, 322 str.

DOI: https://doi.org/10.11567/met.33.3.6

Novi združeni napor Sabrine P. Ramet i Marka Valente, profesorâ s Norveškog sveučilišta znanosti i tehnologije u Trondheimu (Norwegian University of Science and Technology), rezultirao je izdanjem Cambridge Univerity Pressa - knjigom Ethnic Minorities and Politics in Post-Socialist Southeastern Europe. Okupljanjem sedamnaestero autora iz različitih zemalja, među kojima prednjače Sjedinjene Američke Države, Norveška i Hrvatska, u knjizi se raslojava problematika etničkih manjina u zemljama postsocijalističke Europe, a poglavito u zemljama bivše Jugoslavije. Naglasak je pritom, kako i urednici napominju, na proučavanju različitih dimenzija etničkih odnosa te pružanju obuhvatnog pregleda političkih stranaka koje predstavljaju etničke manjine $\mathrm{u}$ ovome dijelu Europe (str. xvii-xviii). Uz navedeno pokrivaju se teme društvene distance, migracija, etničkih granica te državljanstva i integracije prikazani na primjerima političkih stranaka Mađara u Rumunjskoj, Albanaca u Makedoniji, Srba u Hrvatskoj, Turaka u Bugarskoj te različitih etničkih manjina u Crnoj Gori. Šesnaest poglavlja okupljeno je u četiri dijela knjige.

Prvi dio Setting the Scene kroz tri poglavlja uvodi u osnovnu problematiku knjige počevši poglavljem samih urednika »Situating Ethnic Minorities in Post-Socialist Southeastern Europe: an Introduction«. Autori pružaju uvid u etničku strukturu analiziranog područja Europe s posebnim naglaskom na podacima o veličini i proporcijama etničkih manjina te migracijskim obrascima karakterističnim za Jugoistočnu Europu. Također uvode u problematiku etničkih odnosa na prostoru bivše Jugoslavije naglašavajući višestruke poveznice između etničke različitosti, mira i održivosti demokratskog načina života. U sljedećem poglavlju »Ethnic Politics in Post-Socialist Southeastern Europe: an Overview « J. Bugajski analizira neke od najistaknutijih točaka međuetničke napetosti (inter-ethnic friction points) (str. 24) te razmatra moguće scenarije eskalacije konflikta. Tu se ponajprije usredotočio na područja Bosne i Hercegovine, Makedonije, Bugarske i Rumunjske uz dodatnu analizu panalbanskih pokreta na Kosovu. Treće poglavlje u prvom dijelu knjige »Social Distance Toward Ethnic Minorities in Croatia, Serbia, Montenegro, Macedonia, and Kosovo: a Comparative Analysis« priredili su Z. Strabac i M. Valenta. Pozornost su usmjerili na stavove i društvenu distancu etničke većine izražene prema najvećim etničkim manjinama u Srbiji, Hrvatskoj, Makedoniji i Kosovu. U radu razlikuju dvije kategorije prihvaćanja etničkih manjina: 1) otvorenost prema društvenim kontaktima i prihvaćenost pripadnika etničkih manjina i 2) prihvaćenost manjina u kontekstu pozicija moći, pri čemu rezultati njihova istraživanja pokazuju nisku razinu prihvaćenosti etničkih manjina u obje analizirane kategorije. 
Sedam poglavlja u drugome dijelu Political Engagements and Formations ponajprije je usmjereno na analizu političkih stranaka etničkih manjina. A. Braun u poglavlju »Ethnic Minority Parties of Romania « prikazuje političku reprezentaciju etničkih manjina u Rumunjskoj na primjeru Mađara i Roma, najbrojnijih etičkih manjina, a koje se potpuno različito tretiraju na rumunjskoj političkoj sceni. Nadalje, Z. I. Irwin analizira albanske političke stranke u Makedoniji te zaključuje kako su (dvije) albanske političke stranke postale »nevažne« na cjelokupnoj političkoj sceni Makedonije, posebno nakon što je »Makedonija 'maknuta' iz programa EU-a, tijekom stagnacije nacionalne integracije $\mathrm{u}$ zemlji i nakon zatvaranja granice s Kosovom « (str. 79). U šestom poglavlju »The Organization and Political Position of Serbs in Croatia« F. Škiljan donosi pregled hrvatske legislative vezane uz političku reprezentaciju nacionalnih manjina te pruža povijesni pregled pravne pozicije Srba u suvremenoj Hrvatskoj (od 1990.) te analizira političke i kulturne stranke i organizacije Srba u Hrvatskoj u istome razdoblju. »For the Love of Homeland: Croat Ethnic Party Politics in BosniaHerzegovina« J. Subotić poglavlje je u kojem autorica ocrtava političku povijest dviju većih političkih stranaka Hrvata u Bosni i Hercegovini - HDZ BiH i HDZ 1990. Pritom analizira njihove ideološke platforme, odnos s drugim strankama u državi i Hrvatskoj kao »domovini«, ulogu stranaka u ratovima na području bivše Jugoslavije devedesetih godina 20 . stoljeća te njihovu izbornost (str. 121). K. Morrison fokusira se u poglavlju »Ethnic Minority Parties in Montenegro: from Mar- ginalisation to Integration « na začetak i evoluciju manjinskih stranaka od prvih parlamentarnih izbora u Crnoj Gori provedenih 1990., preko raspada Demokratske partije socijalista 1997. i referenduma za nezavisnost Crne Gore 2006., a zaključno sa sedmom godinom nezavisnosti. No autor se ne usmjeruje na stranke najveće etničke manjine - Srba, već prati razvoj stranaka koje ne predstavljaju pravoslavnu većinu, odnosno na bošnjačke/muslimanske, hrvatske i albanske stran$\mathrm{ke}$, te analizira $»$ njihovu ulogu u političkom životu Crne Gore (...) te putanju njihova razvoja od marginalizacije do integracije u vladajuće koalicije« (str. 139). O razvoju Pokreta za prava i slobode (DPS), najstabilnije manje političke stranke na bugarskoj političkoj sceni od 1990., govori M. Spirova u poglavlju »The Movement for Rights and Freedoms in Bulgaria: Beyond the Ethnic Vote«. Osnovna poanta poglavlja koju ističe autorica jest to da je DPS dobar primjer izazova koji »etničke stranke" predstavljaju za demokratsku politiku, no ne zbog očekivanih razloga da te stranke mogu pridonijeti politizaciji i radikalizaciji etničnosti te narušavanju »etničkog mira", već zato što je DPS izašao kao kingmaker ${ }^{1} \mathrm{u}$ političkom životu Bugarske umrežen s mnogobrojnim ekonomskim i medijskim skupinama pridonoseći stvaranju nepovjerenja i razočaranja u političke stranke i demokraciju općenito među Bugarskim građanima (str. 154-155). Zadnje poglavlje u drugome dijelu $»$ Bosniak Politics in

Pojam king-maker u političkom se kontekstu odnosi na pojedinca ili skupinu koja ima značajan utjecaj u imenovanju na pozicije moći (The Free Dictionary, https://www.thefreedictionary.com/kingmaker) iako sam(a) nije kandidat uključen $\mathrm{u}$ izbor. 
Serbia: the Struggle for Recognition, Emancipation, and Historical Revisionism« A. Zdravkovskog opisuje ideologiju i program triju najvećih političkih bošnjačkih stranaka na Sandžaku. Autor raščlanjuje njihov politički program i njihove odnose sa srbijanskom i jugoslavenskom vladom uz poseban osvrt na povijesni revizionizam kao jednu od karakteristika koju su bošnjačke stranke preuzele u svojim programima.

Treći dio Ethnic Boundaries and Inclusion and Exclusion of Ethnic Minorities okuplja pet poglavlja usmjerenih ponajprije na analizu različitih aspekata kreiranja etničkih granica te na mehanizme uključivanja i isključivanja etničkih manjina. I. Culic u poglavlju »Hungarian Society in Romania: Political Project and Practical Reality « raspravlja o naporima Demokratskog saveza Mađara u Rumunjskoj (DAHR), čiji je cilj jačanje institucija koje reproduciraju i podupiru mađarsku kulturu i mađarski narod u Rumunjskoj. Sljedeće je poglavlje »Minority (Serb) Returnees to Croatia: Reintegration or New Immigration? « u kojem su autori M. Mesić i D. Bagić pokušali identificirati ključne političke, ekonomske, sociodemografske, kulturne i druge promjene u Hrvatskoj koje su imale značajan učinak na povratak srpskih izbjeglica u svoja mjesta porijekla u Hrvatskoj. Dodatni je cilj rada bio objasniti veliko smanjenje $u$ proporciji srpske nacionalne manjine $\mathrm{u}$ ukupnome hrvatskom stanovništvu u dvadesetogodišnjem razdoblju od 1991. do 2011. Nadalje, na primjeru Slovenije M. Pajnik u poglavlju »Nationalizing Citizenship: the Case of Unrecognized Ethnic Minorities in Slovenia« upozorava na problematiku »nacionalizacije državljanstva « kroz analizu manjinskih politika u Sloveniji te njihovih učinaka na položaj neslovenskih bivših Jugoslavena, koji čine najveću nepriznatu manjinu u zemlji. Autorica također pokazuje kako »sekuritizacijski pristup « manjinama i migracijama cilja prije svega na očuvanje nacionalnih ideologija, pogoršavajući ionako loše uvjete i prava pojedinih manjina (str. 232). »Ethnic Boundaries and the Position of Minority Groups in Croatian Istria « M. Valente, S. Gregurović i Z. Strabca poglavlje je u kojem se autori usmjeruju na pitanje istarskog multikulturalizma, odnosno na pitanje etničkih manjina $u$ Istri te na društvene procese koji su utjecali na osnaživanje regionalnih političkih opcija i jačanje regionalnog identiteta u Istri, koja je poznata kao tolerantno, multikulturno, bilingvalno područje na kojem obitava jaka talijanska zajednica (str. 247). Zadnje poglavlje trećega dijela knjige »Ethnic Boundaries and Politics in Kosovo« F. Cocozzellija govori o političkoj integraciji manjinskih zajednica u suvremenom Kosovu. Autor preko povijesnog prikaza etničkih odnosa i različitih modaliteta interakcije pojedinih etničkih zajednica, posebno u kontekstu nedavnoga konflikta, raščlanjuje specifičnosti srpske, muslimanske, turske, romske, aškalijske i egipatske zajednice nudeći moguće scenarije budućih etničkih odnosa na Kosovu (str. 263).

U zaključnom dijelu knjige »Afterword: a Few Thoughts about Autonomy and Separatism « urednica S. P. Ramet nudi pregled tema pokrivenih u knjizi, posebice se usmjerujući na ulogu autonomije kao mogućeg rješenja percipiranih problema koji proizlaze iz etničkih različitosti. No napo- 
sljetku autorica zaključuje da »ne postoji jednostavan odgovor na pitanje može li autonomija u bilo kojoj situaciji služiti onima kojima je dana ili ne" te upozorava da treba imati u vidu da priznanje autonomije samo po sebi nije dostatno te da svakako valja uzeti u obzir pitanja ekonomije i infrastrukture te ona koja mogu podijeliti samu etničku manjinu kojoj je autonomija priznata (str. 288). Na samom kraju urednici pružaju niz relevantnih bibliografskih jedinica onima koji žele dodatno produbiti znanje o etničkim manjinama u političkom kontekstu na prostorima jugoistočne Europe, čime dodatno pridonose tome da knjiga postane jedan od nezaobilaznih izvora informacija svima koji se bave političkom reprezentacijom etničkih manjina te mehanizmima regulacije njihova položaja u nekom društvu.

Margareta Gregurović

Institut za migracije i narodnosti, Zagreb 